\title{
Construction of Philosophical Values and the Concept of Penancein Islamic Criminal Law
}

\author{
Danial \\ \{danial.tazkiyainstute@gmail.com\} \\ The State Islamic Institute of Lhokseumawe, Aceh, Indonesia
}

\begin{abstract}
This study aims to cast light onthe philosophical values comprised in every criminal case, and the construction of punishment models in Islamic criminal law. The primary data source of this research are the verses and hadiths that contain the principles and concepts of punishment. Secondary data sources include Tafseer, criminal law, and relevant previous research results. All data is derived from document review and processed through navigation, identification, construction of punishment models, and conclusions. Based on the above objectives and research methods, it is revealed that: First, the philosophical values comprised in the criminal penalization of Islam are equilibrium, justice, humanity, reformative, restorative, preventive, preserving life, moral and repentance as a forgiving excuse. Second, the above philosophical values can be constructed into a contributory punishment model for the renewal of national criminal law. The referred punishment model is the scourging and the qisasdiyat sketch. The latter principle contains the consequences of the birth of a new paradigm in the Indonesian criminal justice system. This new paradigm places not only judges who are entitled to determine the punishment of the perpetrator, but the victim also has the right to punish or release the perpetrator from punishment.
\end{abstract}

Keywords: Philosophical Value, Construction, Criminal Concept

\section{INTRODUCTION}

It is apparent that the attention of Islamic law scientists to Islamic criminal law is proven to be very poor, especially with regard to the system of punishment. During this time, Islamic legal research is more oriented to the study of Islamic law in the field of worship [1], [2], muamalat [3], mawaris, munakahat [4], and other fields [5], while the study of Islamic law in the field of jinayat (criminal) is still very limited. And that too is dominated by empiricalsociological studies of Islamic criminal law [6][7], whereas normative-theoretical studies have not received adequate attention.

It is possible to conduct the review of the field of criminal law on the aspects of legal material, legal structure, and legal culture. In fact, thematerial aspects of the law are important and prior aspects before being transformed into the legal structure and put into force by law enforcer. One important aspect of Islamic criminal law material is the punishment system. It is primarily due tothe fact that it greatly affects the life, freedom, and human dignity. The 
punishment system not only causes loss of soul and freedom, but also shortfall of social disability, poverty, and psychological suffering.

On the other hand, the form of prison sentence that has been put into effect in Indonesia is found to trigger a lot of problems, among them is the problem of prison's over-capacity all over Indonesia, the paradigm and material substance factors that are oriented to institutional crime (prison) and the implementation of the prison law itself [8]. One consequence is the occurrence of prisonization, an adaptation performed by inmates to a particular pain or suffering in prison. Some forms of prisonization are the deprivation of fellow inmates, homosexuals, spying, group fighting, narcotics business, differences in treatment by officers, riots, groupings by region, and the oppressive or threatening behavior of prisoners who aro known to show their loyalty to the non-criminal world [9].

It is expected that Islamic criminal law can sinificantly contribute to overcome the above problems, especially with regard to the system of punishment. Ironically, Islamic criminal law has long been seen as cruel, inhuman and contrary to human rights. Among the samples that are often pinpointed to denote the cruelty of Islamic criminal law is the embracement of the system of corporal punishment, such as hand cuts, scourgings, qisas, and stoning to death. This impression is even heightened as there are many studies examining the application of Islamic criminal law in several Muslim countries such as Iran, Afghanistan and Indonesia (Aceh). Such is particularly led by misapprehension of some Western scientists and Muslims themselves in fathoming Islamic criminal law. In their studies they take more heed on the form of corporal punishment of the normatively-textual Islamic penalization system, rather than exploring the philosophical values, and the concept of criminal prosecution contained in them philosophically-contextually. This condition is very harmful not only for Muslims, but also for mankind at large, given the fact that Islamic law plays an essential role as part of Islamic teachings with an underlying vision and mission to spread affection to the whole universe.

On the basis ofthe above background, this study addresses the following questions: First, what and how are the philosophical values comprised in various criminal forms in Islamic criminal law? Second, how dothe philosophical values contribute to build the concept of criminal penalization of Islam in relation to the context of national criminal law reform?

This research has both theoretical and practical significance and urgency. Theoretically, this research contributes in developing the theoretical dimension of Islamic criminal law, especially about the penal system. Practically, this research is expected to contribute to the effort of reform of the Criminal Code in particular and criminal legislation in general. It is given to the fact that the applicable Criminal Code in Indonesia and some other Muslim countries is a colonial product based on the philosophy of individualism and Western liberalism. Meanwhile, Indonesian Muslims as the largest religious adherents in Indonesia and even in the world have an interest to encourage the birth of the Book of Criminal Law which was underlied by the principles and religious values adopted by a nation.

\section{THEORETICAL REVIEW}

Islamic Shari'ah comes up with a primary vision of realizing the piety of human life in the world and the hereafter [10]. In realizing the aforementioned Islamic vision, the scholars formulated an Islamic mission referred to as maqāsid al-syar"ah (the objective of shari'at), which includes the obligation to preserve religion, the obligation to preserve the soul, the 
obligation to preserve the mind, the obligation to keep the offspring, the obligation to keep the property [11], and the obligation to maintain honor [12]. All the above maqāșid al-syarî'ah are the most basic human rights extracted from the basic values (qiyām al-asāsī) of Islamic law which are also the basic values of Islam, namely tawheed, benefit, justice, equality, freedom, brotherhood, tolerance, helping each other, and excellence. The general principles (ușūl alkullī) are derived out of these basic values, which subsequently are formulated into a practical law (ahkām al-'amalī) which becomes the guide and order to govern human life both as a person and society [13]. Thus, law establishment in Islam should never be in contrary to the vision, mission and basic values of Islamic law as referred.

In the context of Islamic criminal law, the formulation of the penal system should rest on this vision, mission, and basic Islamic values. In order to be able to realize the vision, mission, and basic values of Islamic law, it must be formulated based on the objectives and principles of Islamic punishment. There are four objectives of punishment in Islam, namely; first is aljawābir (deterrence), ie as vengeance, reward, and penance. That is, punishment is regarded as a reward for evil on one side, and frees the offender from guilt or sin on the other [14]. Second is al-jawāzir (preventive or prevention), that is, how to prevent people from committing crimes and warn them [15]. Third is al-ișlāh wa al-tahdhīb (rehabilitative and educative), which is the effort to educate the perpetrator of the offense to realize his mistake in the hope of raisingthe perpetrator's awareness that he keeps away from the offense not because of fear of punishment but fear of Allah SWT. Fourth is restorative justice [16] that is a process whereby parties with an interest in a particular breach collectively seek ways about how to deal with the consequences of the offense and its implications for the future. Therefore, the objective of the restorative justice process is the recovery in a secure community of victims and perpetrators post-conflict resolution between them [17].

Based on the basic values and objectives of the above crimes, it is possible to formulate the principles of Islamic criminal law which covers the principle of legality [18][19], the principle of individual responsibility [20], the principle of no crime in compulsion, the principle of no crime without error, and the principle of no criminal for self-defense. According to the principle of legality no act shall be punishable, except those already laid down in the criminal legislation before it is committed [19]. The principle of individual responsibility affirms the prohibition of transferring faults to others (Surat al-An'ām: 164, anNajm: 38-39, al-Zalzalah: 7-8, and al-Baqarah: 286). The principle of non-criminal in compulsion emphasizes that every offense that is carried out must not be under duress, but on the willfulness and voluntary acts of the perpetrator. Furthermore, the principle of non-penalty for self-defense explains that any person who defends himself and his rights can not be criminally charged (Surat al-Baqarah: 194 and Al-Shūrā: 41). Finally, the principle of no crime without error means that an act is deemed offense if the act constitutes an error according to Islamic law [9]. These principles serve as guidance in formulating a system of punishment in Islam. 


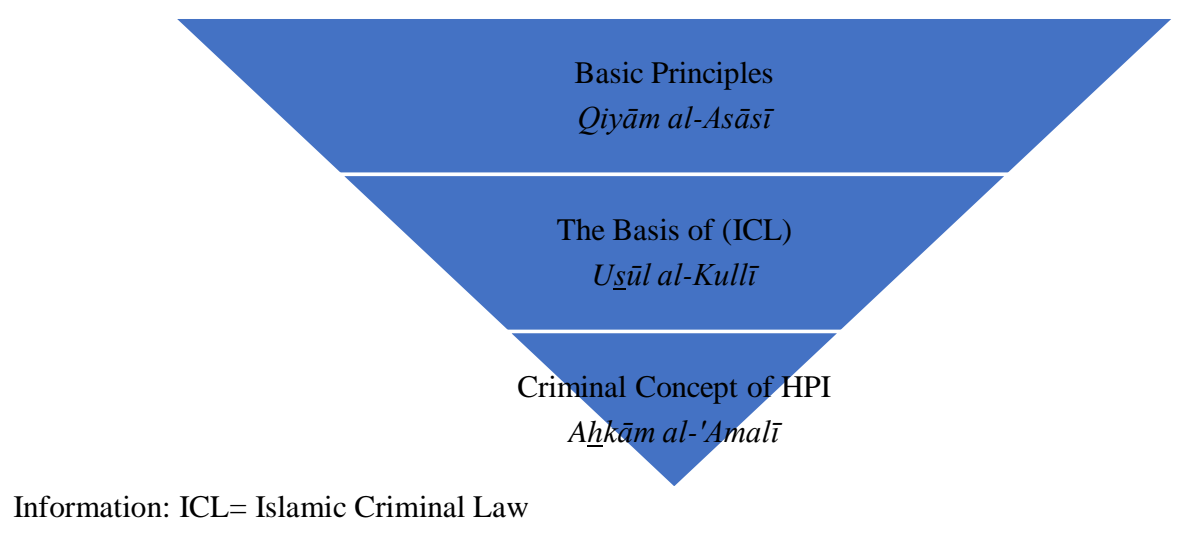

Fig. 1 The Hierarchy of Norm Theory

\section{RESEARCH METHOD}

The verses and hadiths about the crime of hudud and qisas are the primary resources of the research. In tracking the verses referred, the Qur'anic Concordance of 'Ali' Audah is applied, while to navigate the traditions the mu'jam is used as support. Secondary data sources include Tafseer, Hadith (jurisprudence), jinayat fiqh, criminal law literature, philosophy of Islamic law, and relevant previous research results. All data is derived from literature search and processed through the following steps; (1) navigation and identification of verses and hadiths of the hudud and qisas offices (2) inventory of the diversity of punishment forms (through domain analysis); (3) explore the philosophical values comprised in any criminal form (through hermeneutic analysis); (4) construct a new model of punishment that can contribute to national criminal law reform; (5) make a conclusion. The approach used in this research is the philosophy of Islamic law.

\section{RESULT AND DISCUSSION}

\subsection{Construction of Philosophical Values in the Islamic Penal System}

Below is the explanation about the philosophical values comprised in various criminal forms in the Islamic penal system. The intended form of criminal only covers hudud and qisas crime. Each includes the offense of adultery, qadhaf, robbery, drinking khamar, riddah, rebellion, and murder. Based on the results of navigation and analysis of QS. al-Nūr: 2-5; QS. al-Ma'idah: 33-34, 38-39; QS. al-Ma'idah: 90; al-Baqarah: 178-179 and the book of exegesis [21] relating to a number of offenses above the researcher reveals the philosophical values contained therein.

First is the value of balance. This is primarily shown by the bi-dimensional content in the Islamic penal system which includes; (1) the dimensions of the worldly-ukhrawi; (2) the dimension of the severity of punishment and strict of proof; (3) the dimension of the stealing prohibition-order to keep property; and (4) theological-anthropological dimension. The 
dimensions of the worldly-ukhrawi elucidates that the punishment of the offender is not only from the state, but also from Allah swt. If a person is free from the punishment of the world, he will not be free from the punishment of Allah in the afterlife. The existence of the ukhrawi dimension gives birth to an extra legal awareness for society, which inhibits people from lawviolation not for fear of punishment in the world but for fear of punishment in the afterlife. The balance between the severity of the punishment and the strictness of proof is indicated by the punishment of adultery and the proof of four witnesses who simultaneously witnessed the minute action adultery when the penispenetrate the vagina. In this offense an offender may only be subject to punishment if the 4 (four) witnesses are available. A similar balance also applies to the prohibition of stealing and the order of keeping up property for the owner [21].

Second is the value of divinity. This dimension is indicated by the urge and desire to free oneself from the sins of the wrong done. This godly awareness arises from the belief that the punishment in the world will free him from punishment in the afterlife. This theological awareness raises the consciousness of the perpetrator to confess before the Messenger of Allah (PBUH) against the mistakes made [22]. Recognition is a form of repentance to Allah SWT. Repentance is the reformative and restorative step the perpetrator undertakes to repair and break free from sin. Thus, the source of legal behavior, legal awareness, the purpose of punishment, and the motivation to behave in Islamic criminal law is intrinsic because in Islamic criminal law the behavior, awareness, and motivation of law stems from the belief that the slightest mistake will be rewarded by Allah in the Hereafter. It is this ukhrawi dimension that distinguishes Islamic criminal law from secular criminal law.

Third is the enforcement of the value of justice and humanity. This value is shown by Rasulullah SAW in punishing women who have married, while she was pregnant. The Messenger of Allah (PBUH) ordered his guardian to care for the woman and her baby first before being sentenced, including to punish the corpse of the perpetrator who was serving the punishment [22]. This case introduces humanist values in applying criminal to every offender. Treating this human punishment is the philosophy of criminal practice. Thus, Islamic criminal law highly upholds human rights.

Fourth is protection and preservation of marriage institutions through the prevention of all forms of behavior that could harm household harmony or destroy family institutions. Among the prevention forms offered by Islam is the threat of severe punishment for married offenders. The severity of punishment is not intended to punish the perpetrator, but rather based on the purpose of preventing the crime from being committed.

Fifth is uphold of moral values. Because the punishment for the perpetrators of adultery muhșan very heavy, the Islamic criminal law tighten the proof of this offense. A detailed investigation by the Messenger of Allah (PBUH) on the perpetrators who claimed to have adultery [22] proves that in bringing down the criminal, even to the performer who consciously admits to committing adultery it is necessary to have very convincing evidence. The investigation conducted by Rasulullah SAW is not only against the perpetrator (whether he or she is sane or not and whether he or she knows or not that the action is prohibited by law), but also against the deed done. The Prophet's question to one who claimed to have committed adultery; ... [22], is a form of inquiry to obtain information about the act of the offense very convincingly. All those things are etremely necessary to be done in upholding moral values.

Sixth is the value of preventive. This preventive value is contained in many of the offenses in Islamic criminal law, including the offense of adultery. In order to prevent the occurrence of adultery, since the beginning Islam has ordered his adherents to avoid all acts that can direct the perpetrators to adultery. Such actions include, among others, approaching 
adultery (Surat al-Isrā ': 32 ). The prohibition of approaching adultery shows that Islam prioritizes preventive principles, rather than repressive and rehabilitative. This further reinforces the view that Islamic criminal law does not desire to punish, but prioritizes the desire to prevent people from breaking the law. The preventive value contained in the Islamic penal system includes both general and special preventive values.

Seventh is the value of repentance as a forgiving reason. Repentance should be done by the perpetrator before being caught by the authorities in the case of adultery, whilst forgiveness of victims in the case of qazaf (accusing others of illegality without being able to bring in 4 witnesses), and the forgiveness of the victim or the heirs of victim in murder or waivers can free the offender from the threat of punishment . It contains the philosophical value that repentance builds an intrinsic awareness of the law and it also serves to preserve life.

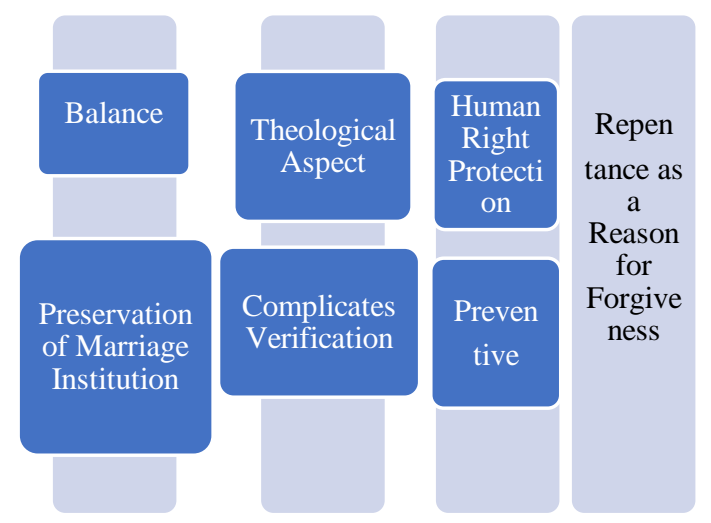

Fig. 2 Philosophical Values in the Islamic Penal System

\subsection{Construction of Penalization Model and Renewal of National Criminal Law}

The above philosophical values contain the ontological, epistemological, and axiological dimensions of Islamic criminal law. The dimension of Islamic criminal law ontology is indicated by the balance and theological values contained therein. Epistemological demands can be seen from the value of the preservation of the institution of marriage and complicates verification. While the axiom of dimension is found in the value of human rights protection, preventive, and repentance as a forgiving reason. Thus, the philosophical construction of the penal system in Islam can be demonstrated as follows:

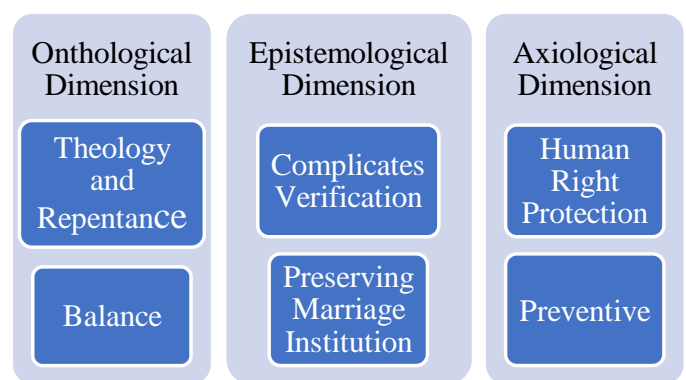

Fig. 3 Philosophical Construction Islamic Penalty 
Ontologically Islamic law is of double dimension. On the one hand, the law is sacred, eternal, absolute, and divine because it comes from God; but on the other hand, it is profane, temporal, relative, and humane because it is the product of human thought and understanding of the Qur'an and Hadith. This double dimension gives birth to a balance between the dimensions of divinity-humanity and the worldly-ührawi/hereafter at the same time. This makes the Islamic criminal law in practice impacts both worldly and in here after. The derivative effect of the nature of Islamic criminal law above is related to the source of obedience, objectives and legal awareness as well as the concept of punishment. Essentially, the source of obedience in Islamic criminal law is internal-intrinsic, rather than based on the expectation of a reward and effort to avoid punishment in the world (compliance) or not by maintaining good relations with the party authorized to apply the rules of law is maintained (identification) [23]. Rather, it comes from an intrinsic theological or intrinsic drive. If the legal consciousness in a secular criminal perspective on the plains can distinguish and behave in accordance with the law or not, the legal consciousness in the Islamic perspective to the plain of consciousness asks to be punished for having violated the law. The awareness of asking for punishment is motivated by (1) the conviction that the punishment in the world is lighter than the punishment in the Hereafter, and (2) the conviction that the execution of the law in the world will liberate every offender from sin and punishment in the Hereafter. Thus, the revision of the national Criminal Draft Law based on the excavation of values sourced from religion, especially Islam is a manifestation of the formulation of criminal law in accordance with the law of living and believed by a religious Indonesian society. Criminal laws formulated based on values and laws that are believed and thrive in society will make the law effective.

An essential reference in formulating the provisions of Islamic criminal law is the basic values and aims (axiology) of Islamic law which is also the goal of Islamic criminal law, namely the benefit of human beings in the world and the hereafter. To achieve such purpose, Islam offers a framework called al-maqāsīd al-syarīah, a basic framework oriented that criminal provisions will manifest human good if it is based on efforts to preserve religion, soul, property, lineage [11] and honor [24].

The foregoing basic values of Islamic law are in line with the basic values of Pancasila as can be systematically abstracted from the first to the fifth; basic values of divinity, humanity, unity, populism, and social justice. While the basic norm (groundnorm) of the 1945 Constitution is not classified as part of a positive law, but transnational-logic that is above positive law. Nevertheless, the 1945 Constitution becomes the determinant of the validity of all positive legal arrangements so that the position of the 1945 Constitution becomes a touchstone for various products of legislation in Indonesia [25][26].

In regard to the concept of punishment, there are several things to be the main ideas of research results, that is related to criminal purposes and philosophical values contained in various forms of punishment. All this time, the penal system policy seems to be highly oriented towards the offenders(offenders oriented), instead of crime victims. This is highly observable, among others, from the following objectives of punishment formulation; (1) the criminal must be able to re-populate the convicted person to be a good and useful person; (2) the criminal should be able to free his guilt; and (3) the criminal must not share and degrade human dignity [27]. In such a context, a judicial or psychological legal policy concerning the interests of crime victims as reflected in the above concept of Islamic criminal thought should be considered in order to contribute to the revision of the upcoming bill of the Penal Code to be a counterweight to an offender oriented legal policy. Thus, there is a balance between the 
orientation to the offender and the victim of a crime, so that the rights of the perpetrator and the rights of the victim are protectedequally.

There are 2 (two) criminal forms that can significantly contribute to national criminal law reform, namely scourging and qișāss. The scourgingis totally foreign in the Criminal Code and the law outside the national Criminal Code. Whereas the qișāsfor criminal offender of deliberate murder is essentially the same as the capital punishment which is known in various regulations applicable in Indonesia. The scourgingis proven to be effective in achieving the purpose of punishment. On this subject there are several arguments that can be put forward as a basis for the imposition of caning criminal in the national Criminal Code in the future.

Firstly, it is obvious that imprisonment has caused many negative effects, such as isolating inmates from the outside world, robbing the inmates from the power to decide the important aspects of their life, making them prone to live in an oppressive and violent jail environment, and a bad environment for their health, especially for the elderly [28]. The inhumane situation in many prisons resulted in anger and destructive hatred. As a result, prisons can produce criminals who have a greater tendency to take revenge against their society upon theie breakfree.

Second, scourging can give a sense of deterrence both physically and psychologically. The purpose of the imposition of a criminal scourging for the offender is to offset the psychological factors that encourage the offense, namely to get pleasure. Psychological factors that oppose to it is a condition that leaves a former threat of misery or pain, especially spiritual pain (shame). Thus, it is expected that the criminal can prevent the perpetrator to repeat his actions [9].

Thirdly, scourgingis economically effective, because it can save state costs, especially when compared with imprisonment, because scourging does not require the provision ofprison buildings and the additional living costs for the needs of the prisoners. In addition, punishment can prevent deterioration in the productivity of the convict, because its implementation does not last long, so after serving the punishment the convicts can return to work as usual.

The next criminal form that contributes to the reform of the national criminal law is the law of qișaș. The contribution offered here is oriented towards the philosophical value embodied in it. The death penalty in Islamic law is applied to a deliberate killing offense that is not excused by the victim's family. In other words, upon the forgiveness of the victim's family, the perpetrator is not required to serve a penalty, instead, he or she will be required to pay diyat (indeminity) for the victim's family. In this provision, there are 2 (two) concepts that Islam wants to offer for qiṣās, especially qișāṣ for death, namely (1) the concept of equilibrium (qiṣāṣ) and (2) the concept of forgiveness.

Philosophically the purpose of qișaș is preventive and restorative. The preventive purpose is meant to prevent the crime of subsequent murder and at the same time prevent the community from 2 (two) things, namely: (1) revenge between the victim's family and the perpetrator that can result in the birth of social chaos, therefore Islam authorizes the government to enforce the law of qișaș; (2) preventing other people or the community from taking the same action (killing) at a later time, because the offense of murder is threatened with a very serious crime. This restorative goal is not only for the perpetrators and the relationship of the perpetrator with the victim's family in one social life order, but also for the society at large. Restoration or improvement of this behavior is the principle of education in order to educate a criminal to turn into a good person. Therefore, in the criminal structure of killing, the law of qișās is the highest form of punishment. That is, it is applied as the last alternative if the victim's family or heir does not forgive the offender. 
In Islam, the law of qișāṣ contains both criminal and civil elements. The criminal element is the qișās criminal penalty for any offender of deliberate killing that has already fulfilled the terms of the qișās offense. While the civil element is the right of the victim's family to forgive the perpetrator to be not only free from the qișās criminal, but also to be free from diyat payments, upon the willingness of the victim's family.

Meanwhile, according to Islam, the two types of criminal qișāṣ and criminal diyat above, are conceptualized as the principal punishment whose criminal imposition is left to the victim or the victim's family as the owner of the right through the verdict of the judge. Based on this, it is clearly seen that the concept of Islamic criminal law has a stronger commitment to the issue of the need for legal attention to victims of crime as those who experience the consequences of a crime. Therefore, the aforementioned concept of Islam should be considered as an ingredient to be accommodated in the review and refinement of the upcoming Criminal Code Bill. It is highly suggested to consider the Islamic Law with regard that the Indonesian criminal law in the future is designed to become a balanced and proportional law between the victim oriented and offender oriented. This also given to the fact thatat present, the vision of victimology has become a commonplace international trend which also colored the concepts of modern criminal law. Therefore, the Criminal Code Bill should ideally adapt to the international trend by adaptive reasoning as one of the basic reforms of Indonesian criminal law (Penal Code).

Thus, the qișāṣ-diyat criminal sketch can be offered as a model of restorative justice. In this concept it is understood that criminals and crimes are solved in a participatory manner by involving perpetrators, victims, and communities. This restorative justice aims to: (1) educate the perpetrator to acknowledge his mistakes and learn to be responsible for his (educative) mistakes; (2) recover the victims (rehabilitative or restorative); and (3) realize public order [29].

Based on some of the above, the idea to offer the values or principles contained in the form of criminal as well as alternative criminal forms of scourging and capital punishment to be included in the Criminal Code Bill is part of the norm and construction of national criminal law reform. For, philosophically, juridically, and sociologically these values or principles and criminal forms are in accordance with the values of Pancasila, the 1945 Constitution and the legal awareness that lives within the cosmos of the religious personality of Indonesian society. 


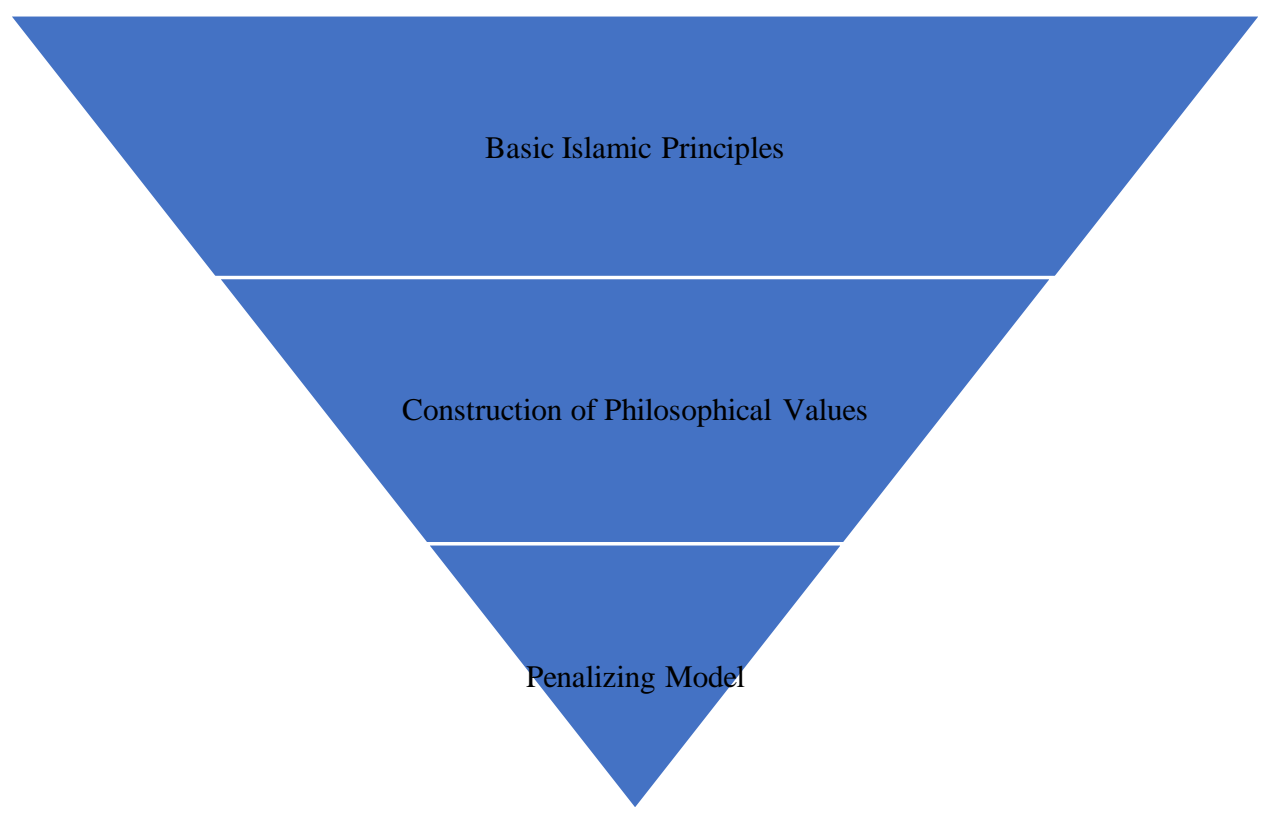

Construction of Philosophical Values and Models of Penalizing Islamic Criminal Law

\section{CONCLUSION}

Based on the above explanation it is possible to conclude that:

First, the true philosophical values in various forms of punishment in Islamic punishment include; (1) the balance between ilāhiyyah (theological or divine) values and insāniyah (anthropological or humanitarian), the world and the hereafter, the protection of the rights of the perpetrator and the victim, the criminal and the offense, the criminal to the offender and the obligation to close the possibility of the offense and the balance between (2) protection and upholding the values of justice and humanity, (3) upholding moral values, especially the value of honesty and responsibility, (4) the value of reformative and restorative justice, (5) protection and preservation of marriage institutions, (6) prioritizing preventive rather than repressive, (7) preserving life, (8) repentance as excuses, and (9) the greater the threatened punishment, the more strict the evidence needed.

Secondly, based on the construction of the philosophical values embodied in various criminal forms, it is possible to formulate not only a more effective and efficient punishment model but also other non-criminal and legal measures that can be offered by Islamic criminal law. With regard to the punishment model, this study finds a model of scourging and qisasdiyat sketches as one of the concepts of effective and efficient punishment because scourging has economic, psychological and social effectiveness, and better protection of human rights. The qisas-diyat sketch offers two important concepts of crime. First is being sensitive to the victim / family of the victim along with the rights attached to it. Second is the restorative justice paradigm. In addition, the study also found that in tackling future crimes it is not enough to use the juridical approach only through the imposition of sanctions, but also on economic and social policies. Thus, the state can punishevery perpetrator of theft only if it has 
prospered its people because in terms of Islam, stealing because of hunger is not a crime, unless it is caused by greed and voracity.

\section{REFERENCES}

[1] H. Thaib and S. Sofyan, "Teknik Pembuatan Akta Penyelesaian Warisan Menurut Hukum Waris Islam Di Indonesia." Citapustaka Media, Medan, 2014.

[2] A. G. Anshori, Pokok-Pokok Hukum Perjanjian Islam di Indonesia. Citra Media, 2006.

[3] S. Anwar and H. P. Syariah, "Studi tentang Teori Akad dalam Fikih Muamalat," Jakarta Raja Graf. Persada, 2007.

[4] M. Satria Effendi, "Zein, Problematika Hukum Keluarga Islam Kontemporer: Analisis Yurisprudensi dengan Pendekatan Ushuliyah.” Cet. I, Jakarta: Prenada Kencana, 2004.

[5] J. R. Bowen and J. R. Bowen, Islam, law, and equality in Indonesia: An anthropology of public reasoning. Cambridge University Press, 2003.

[6] M. J. Habibzadeh, "Legality principle of crimes and punishments in Iranian legal system," Educ. Res. Rev., vol. 1, no. 3, pp. 108-114, 2006.

[7] C.-V. Maftei, "The Sanctions Of The Islamic Criminal Law. Aspects Regarding Penalties Of The Criminal Law Of The Islamic Republic Of Iran. Religion And Tradition Vs. Observing Human Rights," Curentul Juridic, Juridical Curr. Le Courant Jurid., vol. 3, pp. 139-148, 2010.

[8] A. Angkasa, "OVER CAPACITY NARAPIDANA DI LEMBAGA PEMASYARAKATAN, FAKTOR PENYEBAB, IMPLIKASI NEGATIF, SERTA SOLUSI DALAM UPAYA OPTIMALISASI PEMBINAAN NARAPIDANA,” J. Din. Huk., vol. 10, no. 3, 2016.

[9] Danial, "Fikih Mazhab Iran dan Aceh," UGM Yogyakarta, 2015.

[10] I. Q. Al-Jauziyyah, I'lām al-Muwāqi'īn 'an Rabb al- 'Ālamīn, III. Beirut: Dār al-Jayl.

[11] A. I. As-Syāțib̄̄, al-Muwāfaqāh fì Ușūl al-Syarī'ah, I. Kairo: Mușțafā Muḥammad.

[12] A. G. Anshori and Y. Harahab, Hukum Islam: dinamika dan perkembangannya di Indonesia. Total Media, 2008.

[13] S. Anwar, Studi Hukum Islam Kontemporer. RM Books, 2007.

[14] A. F. Bahanthi, al- 'Uqūbah fì al-Fiqh al-Islāmī, III. Kairo: Maktabah al-Wa'̄̄ al-'Arabī, 1980.

[15] N. F. Wașil, Fiqh al-Jināyah wa al- "Uqūbah fì al-Syarī”ah al-Islāmiyyah. Kairo: Maktabah alȘafâ, 1999.

[16] Octoberrinsyah, "Hukuman Mati dalam Islam dan Relevansinya dengan Hukum Pidana Indonesia," UIN Sunan Kalijaga, 2011.

[17] A. Duff, "Restoration and Retribution: Competing or Reconcilable Paradigms?," in Restorative Justice and Criminal Justice: Competing or Reconcilable Paradigms?, A. von Hirsch, Ed. Hart Publishing, 2003.

[18] 'A. Q. Audah, al-Tasyrī' al-Janā' ’̀ fi al-Islāmī, I. Beirut: Dār al-Kutub al-'Ilmiyyah, 2005.

[19] E. S. O. Hiareij, Pengantar Hukum Pidana Internasional. Jakarta: Erlangga, 2009.

[20] M. Halim, Asas-asas Negara Hukum Indonesia dalam Islam; Kajian Komprehensif Islam dan Ketatanegaraan. Yogyakarta: LKiS, 2010.

[21] M. Q. Shihab, Tafsir al-Misbah, III. Jakarta: Lentera Hati, 2005.

[22] A. I. H. 'Asqalān̄̄, Ibānat al-Ahkām; Syarh Bulūgh al-Marām, III. Beirut: Dār al-Fikr, 2006.

[23] A. Achmad, Menguak Teori Hukum (Legal Theory) dan Teori Peradilan (Judicial Prudence) termasuk Interpretasi Undang-undang (Legis Prudence). Jakarta: Kencana, 2009.

[24] M. S. R. Al-Būṭ̂̄, Dawābiṭ al-Mașlaḥah fì al-Syarī'ah al-Islāmiyyah. Kairo: Mu'asasah alRisālah.

[25] B. L. Tanya, T. Y. Parera, and S. F. Lena, Pancasila bingkai hukum Indonesia. Genta Publishing, 2015.

[26] T. Prasetyo, "Kriminalisasi dalam Hukum Pidana Islam." Nusamedia, Bandung, 2013.

[27] Indonesia Corruption Watch, "RUU KUHP 2013," 2014. [Online]. Available: https://antikorupsi.org/id/news/ruu-kuhp-2013. [Accessed: 02-Mar-2017]. 
[28] M. Costanzo, Psychology Applied to Law: A Friendly Introduction. Wadsworth Pub Co, 2004.

[29] R. Yulia, "Penerapan Keadilan Restoratif Dalam Putusan Hakim: Upaya Penyelesaian Konflik Melalui Sistem Peradilan Pidana,” J. Yudisial, vol. 5, no. 2, pp. 224-240, 2012. 